\title{
Anhelo Cognitivo y Muerte DeL IDEAL EN LA LÍRICA COLOMBIANA*
}

Fecha de recepción: 11 de octubre de 2013

Fecha de aprobación: 22 de noviembre de 2013

\section{Resumen}

El presente artículo ofrece una lectura de algunos debates sobre el "saber" y el compromiso mimético del poema en la lírica colombiana de finales del siglo XIX y principios del XX, tomando como eje el problema de la verdad y el código hegemónico de representación del cuerpo femenino. Estudiaremos cómo el proyecto finisecular de la lírica colombiana centró sus ideales en una dependencia heterónoma de la poesía, apoyándose en el dominio prescriptivo del lenguaje y en la feminización del poema. Veremos, así mismo, cómo sus estrategias de validación canónica son impugnadas en el siglo XX por la visión antimetafísica de poetas como Luis Carlos López, Héctor Rojas Herazo, Raúl Gómez Jattin y María Mercedes Carranza.

Palabras clave: poesía, ideal, conocimiento, lenguaje, gramática, código corporal femenino.

* Este artículo hace parte de la investigación "El jardín, la torre y la lámpara: hacia una cognición poética en la lírica colombiana”, XV Beca de Investigación Cultural Héctor Rojas Herazo (Observatorio del Caribe Colombiano-Ministerio de Cultura de Colombia, 2013).

Citar: Santos García, E. (Enero - Junio de 2014). Anhelo Cognitivo y Muerte del Ideal en la Lírica Colombiana. La Palabra (24), 45 - 58

\author{
Emiro Santos García \\ Universidad de Cartagena, \\ Colombia \\ esaga17@gmail.com
}

Magíster en Literatura Hispanoamericana y del Caribe de la Universidad del Atlántico. Profesional en Lingüística y Literatura de la Universidad de Cartagena. Es autor de los libros de investigación literaria Héctor Rojas Herazo. El esplendor de la rebeldía (2011), Cartografías de la imaginación (2013) y de los libros de cuento Retorno a las catedrales (2012) y El vértice de la noche (2006). Director de Visitas al patio, revista del programa de Lingüística y Literatura de la Universidad de Cartagena. Actualmente se desempeña como docente de Literatura en esta universidad. 


\title{
la palabra
}

\section{PoETRY AND KNOWLEDGE: \\ Cognitive Urge and Death of the Ideal IN THE COLOMBIAN LYRIC GENRE}

\begin{abstract}
This article offers a reading of the debates on "knowledge" and mimetic commitment of the Colombian lyric poem in the late nineteenth and early twentieth centuries, focusing on the problem of truth and the hegemonic code of representation of the female body. We will study how the project of Colombian poetry in the late XIX century was based on the heteronomous dependence of poetry, relying on a prescriptive mastery of language and the feminization of the poem. We will also analyze how the canonical validation strategies of this project are challenged in the twentieth century by the anti-metaphysical vision of poets such as Luis C. López, Hector Rojas Herazo, Gonzalo Arango, Raúl Gómez Jattin and María Mercedes Carranza.
\end{abstract}

Key words: poetry, ideal, knowledge, language, grammar, code of representation of the female body.

\section{Pó́sie et Connaissance: Desir Cognitif et Mort de L'ideal Dans la LyRiQue ColOMBIENNE}

\section{Résumé}

Cet article offre une lecture des débats sur le «savoir» et le compromis mimétique du poème dans la lyrique colombienne de la fin du XIXème siècle et du début du XXème siècle, en prenant comme axe le problème de la vérité et le code hégémonique de représentation du corps féminin. On va étudier comment le projet finiséculaire de la lyrique colombienne a centré ses idéaux sur la dépendance hétéronome de la poésie, en s'appuyant sur la maîtrise prescriptive du langage et sur la féminisation d poème. On verra, de la même façon, comment ses stratégies de validation canonique, sont défiées au XXème siècle, pour la vision antimétaphysique de poètes comme Luis C. López, Héctor Rojas Herazo, Gonzalo Arango, Raúl Gómez Jattin et María Mercedes Carranza.

Mots clés: poésie, idéal, connaissance, langage, grammaire, code corporel féminin. 
Las sílabas del dios: la gramática de la verdad

En 1910, Luis Carlos López, en compañía de Abraham Zacarías López Penha y Manuel Cervera, publica un libro en el cual incluye uno de los poemas más sugestivos de la poesía colombiana. Deudor de una poema en prosa como "La pérdida de la aureola", de Baudelaire, "Esto pasó en el reinado de Hugo" cuenta la historia de un hombre -acaso antiguo sacerdote o depositario de los misterios de la trascendencia- que, al subir "la escalera del ideal/ siguiendo una ilusión" (2007, p. 139), resbala hasta el infame mundo de las sombras. El poeta no se duele, sin embargo, de la degradación o los daños causados al ideal: "Me atormenta/ y mortifica// mucho más el daño/ de una cuenta/ que adeudo en la botica" (p. 139). Nos encontramos, a principios del siglo XX en Colombia, con un flagrante rebajamiento de la "dignidad" de la palabra poética ${ }^{1}$.

¿Cómo considerar las implicaciones de este abandono de la figuración espiritualista? ¿Dónde queda la elevación inmaterial de poetas como Pombo, Núñez, Mora o Valencia? Irónico, pedestre, desencantado, si se quiere, el soneto de López violenta los tradicionales modos de representación de un fundamento metafísico para la poesía, construyendo un materialismo en contravía a las preceptivas clásicas. Para estas, así como para algunas teorizaciones románticas -pensamos en Schiller-, la belleza es solo posible en la medida en que no es mancillada: la plena realización desemboca en una traición del vuelo. "Cuando viene el goce del sentido", escribe en 1908 el crítico cundinamarqués Roberto Cortázar, "lo espiritual se trueca en materia, el arte desaparece dejando el recinto vacío" (2003, p. 118).

La fundación de un ideal extralingüístico promete una esencialidad eidética, una realidad más allá de las contingencias de la historia, donde el poema -como composición verbal- vibra en la reflectividad del universo. De ahí las implicaciones transgresoras de la poesía de López: su afrenta se dirige no sólo a las premisas formales de la poesía hegemónica colombiana, sino a su legitimidad como camino para alcanzar una verdad más allá de los signos. ¿Cómo reconocer la presencia inmutable de lo poético? Y sobre todo, ¿qué clase de saber alcanza a proveernos, si es ahora el suyo un mensaje opaco e ilusorio?
La poesía de López reclama una inesperada profundidad, más afín a un pensamiento liberado de las trampas del logos metafísico, menos cercano a la palabra como espejo del mundo. Rafael Núñez, intelectual que persiguió un fundamento ahistórico en versos de frágil estro, ejemplifica muy bien la pretensión de encontrar una realidad más acabada y perdurable: "Hay un mundo sin formas, inefable,/ Mundo moral, inmenso, imponderable,/ Donde no han podido existir sombras ni error;/ Mundo sin polos, ni zodiaco, eterno,/ Antítesis de aquel horrible infierno/ Que, en el Dante, epopeya es del dolor" ("Lo invisible") (Núñez, 1986, p. 63).

Poesía filosófica, científica y sabia, como afirma irónicamente Baldomero Sanín Cano (1977, p. 42), asistimos en los versos de Núñez a un agotamiento programático de los ámbitos más variados del conocimiento -Filosofía, Teología, Psicología, Física, Botánica, e incluso sentencias de aliento sapiencial: "La vida es vanidad de las vanidades,/ Unas tras otras pasan las edades/ Y nada nuevo jay! vemos venir" ("Imitación al Eclesiastés”) (Núñez, 1986, p. 51)-. El poema en Núñez se convierte en una ausencia, en el discurso

1 Ya antes lo había hecho, solo por un momento, Manuel María Madiedo, al oponer la viril naturaleza del trópico a las delicadas remembranzas de la Grecia clásica: “¿Qué fuera aquí la fábula difunta/ De las ninfas de Grecia afeminada, / Al lado del tremendo cocodrilo/ Que sonda los misterios de tus aguas" ("Al Magdalena") (1859, p. 137). Pero su doctrinarismo católico impide la asunción de nuevas formas de belleza. Anota José Joaquín Ortiz, prologuista del libro publicado por el cartagenero en 1859, que hay en sus versos "bella espresión [sic] de lo bueno i [sic] de lo verdadero", "fe pura", "altas verdades" y "esperanza consoladora del cristianismo" (VI-VII). 
de otro lugar, más legítimo y verdadero por cuanto abreva en la universalidad de la revelación sagrada, o en las conquistas de la ciencia. No de otro modo se explica la incisiva arremetida de Baldomero Sanín Cano contra las pretensiones heterónomas del "vate-filósofo". No lo denuesta el antioqueño por su menguado rigor científico -nada más distante del esteticismo del crítico, que en esto sigue a Baudelaire-, sino en tanto su pretendida convalidación empírica es falseada por errores cognitivos y de ejecución ${ }^{2}$.

Semejante disputa, que cancela la vigencia del poetagramático decimonónico -al menos en términos propositivos: la lírica colombiana continúa perpetuando, hasta mediados del siglo XX, ideologías ancilares-, permite rastrear un punto de quiebre en el representacionalismo lingüístico de la poesía tradicional, vital a la hora de comprender el lenguaje roto de Héctor Rojas Herazo, el onirismo de Giovanni Quessep Esguerra o la ironía lúdica de Rómulo Bustos Aguirre. Incluso un poeta tan moderno como José
Asunción Silva no abandona del todo una concepción analógica del ser. En "La protesta de la Musa" vislumbramos un gesto que "anula" de un trazo uno de sus conjuntos de poemas más renovadores: la colección de Gotas amargas ${ }^{3}$. En esta prosa el bogotano condesciende, muy a pesar suyo, con un ideal evanescente, espiritual. Después de adentrarnos en un cuarto "sencillo y triste", nos enseña cómo la Musa -luz de madrugada- desciende a la tierra y pregunta por el libro que el poeta escribe. Este, tembloroso y demudado, confiesa que ha compuesto "un libro de sátiras" (Núñez, 1986, p. 355). La voz de la Musa se vuelve terrible: "Sigue profanando los versos sagrados y conviértelos en flechas que hieran, en réptiles que envenenen (...) a riesgo de mancharte, tú que podrías llevar una aureola si cantaras lo sublime" (p. 357).

"La protesta de la Musa" es particularmente interesante por el juego de relaciones intrapoéticas que establece con poemas como "Esto pasó en el reinado de Hugo" (1910), de López, "Contrapunto para glosar el martirio de San Lorenzo"
(1961), de Rojas Herazo, o "El Arcángel" (2004) y "Mirando una estampa de Santa Lucía" (2004), de Bustos Aguirre. En ellos, a diferencia del poema "Sursum", de Núñez (1986) donde se celebra la "aureola sobrehumana" con la que el hombre se libera de la "presión profana" (p. 134) ${ }^{4}$ - persiste un descentramiento del halo: un rebajamiento de lo divino que, en el caso de Rojas Herazo, re-escribe el martirio cristiano, convirtiéndolo en un fuego ciego o en la promesa nunca formulada por un cielo del cual no se tiene certeza, y en Bustos Aguirre, contamina de ambigüedad la iconografía religiosa del vuelo angélico y las ofrendas del martirio."La protesta de la Musa", sin embargo, es igualmente sugestiva por su hexis imaginaria: la separación entre un arriba luminoso, etéreo, y un abajo turbio y oscuro. La "aureola divide la vida", sostiene Berman, "[...] la figura santificada es arrancada de la matriz de la condición humana, inexorablemente separada de las necesidades y presiones que animan a los hombres y mujeres que la rodean" (2008, p. 113) $)^{5}$.

2 "El cerebro secreta pensamiento/ Como la caña miel” (Núñez, citado por Sanín, 1977, p. 47). Esto es un "disparate", afirma Sanín Cano: "El cerebro no excreta ni secreta nada; pero mucho menos puede tener secreciones como la caña de azúcar” (p. 48). Para una lectura de la importancia de la crítica de Sanín Cano en la literatura colombiana, véase Cobo Borda (1978, pp. ix-xiii) y Jiménez Panesso (1992, p. 72-124).

3 "En Silva", escribe Fernando de la Vega, a mediados del siglo pasado, "adquiere la poesía contornos renovadores, aunque no abiertamente iconoclastas" (1981, p. 115).

4 "La corporal figura/ del hombre, dominada por su mente", dice la estrofa completa, "formas etéreas cobra en ocasiones, y entonces, libre de presión profana,/ brilla con aureola sobrehumana” (las cursivas son nuestras) (Núñez, 1986, p. 134).

5 Advierten Berman y Benjamin las consecuencias de la pérdida de la aureola, o el aura, en la poesía y el pensamiento moderno: la desacralización del mundo. "La burguesía", cita Berman a Marx, "ha despojado de su aureola a todas las profesiones que hasta entonces se tenían por venerables y dignas de piadoso respecto" (2008, p. 103). En el especial caso del arte, como señala Benjamin (1973), se pierde la "manifestación irrepetible de una lejanía”, o su antiguo carácter cultual (p. 24). 
$¿$ Radica en esta gravidez una de las claves para comprender las dinámicas secularizadoras de la modernidad? ${ }^{6}$ Más aun, ¿podríamos afirmar que es el problema de la verdad uno de los elementos constitutivos del ideal poético en la lírica colombiana de finales del siglo XIX y principios del XX? David Jiménez Panesso (1994), en Fin de siglo, decadencia y modernidad, ha adelantado una aproximación a las visiones morales y religiosas de la poesía finisecular colombiana, advirtiendo que la preocupación por las relaciones entre "ficción" y "verdad" es imprescindible a la hora de su estudio. Si bien no detalla siempre las formas concretas en que este proyecto se realiza en el poema, suministra un valioso recorrido por los conflictos ideológicos entre románticos, clásicos y modernistas: sus pretensiones teológicas que colindan más de una vez con formas espurias de la mística.

En su artículo "Poesía", publicado el 17 de julio de 1888 en La Nación, Núñez retoma las certidumbres de Miguel Antonio Caro: la verdad de la poesía -superior a la ciencia-, se confunde con "la religión, aspirando a lo infinito". Un neomisticismo que propende por la restauración de la religiosidad asaltada por el realismo naturalista y el materialismo positivista (Jiménez, 1992, p. 55). La exaltación del mundo orgánico y cotidiano es vista así como un obstáculo para acceder a niveles cada vez más altos de idealidad, corrompiendo la serenidad de la contemplación. Tanto el idealismo propuesto por Núñez como el innatismo de Caro -su fe en la "región más alta del alma, en donde la vista desfallece y el corazón se siente poseído de un temor religioso" (1962, p. 452) - buscan prescindir de los sentidos materiales, para encontrar una pureza moral que resida en el alma y ennoblezca el arte.

Ya en la década del veinte, sin embargo, Jorge Guillén cuestiona en España propuestas como estas, representadas en su momento en la figura del abate francés Henri Brémond, para quien, según el poeta vallisoletano, la poesía respondería a un estado místico, inefable. "No hay más poesía que la realidad en el poema”, disiente Guillén, " $y$ de ningún modo puede oponerse al poema un estado inefable que se corrompe al realizarse y que por milagro atraviesa el cuerpo poemático" (1997, p. 707). Para Brémond, más allá de intelectualismos o preceptivismos academicistas, la verdadera poesía -la poésie pure-concierne a una intuición irracional del ser. Pero como obligado corolario esto complica una supresión tanto de las fronteras genéricas como de la materialidad del discurso poético, cuyo "soporte" formal no es para nada deleznable durante la vigencia del humanismo clásico colombiano (cf. Deas, 2006). La pregunta vuelve entonces a nosotros con otra fuerza, no solo referida a los vínculos ideológicos entre "ficción" y "verdad", sino al sistema simbólico en el cual se plantea la aspiración metafísica y a la forma como es interpelado por diversos poetas.

Tal vez con ello arribemos a una pregunta por la posible naturaleza del lenguaje poético; pero antes de asumir los riesgos de una ontología general -distante, en todo caso, de una filosofía especulativadebemos comprender cómo ocurren los vínculos entre poesía y gramática en la legitimación del ideal trascendente de la poesía colombiana, para así entender cómo algunos autores posteriores desarticulan, en el orden del lenguaje, un orden óntico del mundo. No nos detendremos aquí en una revisión historiográfica -Deas (2006), von der Walde (1997, 2002) y Niebles (2007) han revisado con suficiencia los proyectos políticos nacionalistas, o incluso continentales, centrados en el dominio de la gramática como soporte

6 Hugo Friedrich (1958), en La estructura de la lírica moderna, habla de "trascendencia vacía" o "vacuidad del ideal". Walter Schulz (1961), en El dios de la metafísica moderna, se refiere a una desustancialización de la trascendencia en el pensamiento ateo moderno. 
de una "alta" cultura ${ }^{7}$, sino en sus consecuencias ideológicas en el poema. Es decir, en cómo el principio religioso propuesto por Núñez (1970) como base de un "orden interior" y un "orden moral", y la normativización lingüística adelantada por Caro y Cuervo -que resalta el carácter "espiritual" de la lengua castellana (Caro, 1920, p. 52)-, perfeccionan una retórica naturalizada del lenguaje.

Como advierte von der Walde (2002), esta retórica marginó al resto de un país "plagado de hablas regionales en las que incluso se escribe poesía y narrativa, pero que quedan excluidas de la verdad, de la palabra por ser desviaciones de la norma". Puede comprenderse mejor entonces la apuesta dialectal de Candelario Obeso o la postura del escritor bogotano José María Vargas Vila -vilipendiado durante mucho tiempo por las élites conservadoras- al oponerse, con su oblicuo estilo literario, al poder de una ortodoxia. "Es por eso, que todos los errores $\mathrm{y}$, aun los horrores, hallados por el vulgo de éticos y de clásicos, en mis libros, han sido voluntarios, deliberada y conscientemente puestos allí (...) para demostrar con ellos, cuán distante estoy yo, de todos esos rebaños letrados o semiletrados que pacen en las dehesas anacrónicas de la Tradición" (Vargas Vila, 1999, pp. IX-X).

Reducida a decorosa cobertura, la poesía deviene en receptáculo, en axioma que no procede de las reflexiones modernas sobre la particularidad de la forma artística, sino del racionalismo lingüístico heredado de las consideraciones platónicas, aristotélicas, tracianas y priscianistas, para las que el lenguaje opera como expresión articulada del pensamiento. No deja de ser ilustrador el tratado de métrica publicado por Manuel María Madiedo en 1859. En sus páginas, el intelectual cartagenero define palabra como "todo signo articulado que exprese una idea por lo menos" ( $p$. 37), pues, siendo "las palabras los signos representativos de nuestras ideas, deben ser, en lo posible, sus verdaderas imágenes” (p. 38). ¿Qué vela esta concepción del signo? ¿Qué nos dice del verso en la retórica decimonónica? Debemos anotar, ante todo, su procedencia desde los terrenos de la lógica formal para valorar sus consecuencias epistemológicas.

Señala Benveniste que cuando el Estagirita intenta delimitar el estatuto lógico de los predicados del Ser no reencuentra más que las categorías de la lengua en la que piensa: el lenguaje del filósofo es el lenguaje de la lengua escrita, codificado y traspuesto al plano noético Vernant, 1982, p. 172). El poeta español Antonio Machado ve en esta peculiaridad una pretensión destemporalizadora que es ajena al poeta. A diferencia de las pretensiones de la Filosofía, al poeta no le es dado discurrir por fuera del tiempo -desde cápsulas lógicas o abstractas-, sino en el tiempo, que es su inevitable realidad psíquica (Machado, 2001, p. 81). Por su parte, en El ocaso de los ídolos, Nietzsche juzga la gramática como una forma soterrada de teología, al sustancializar las categorías verbales, confundiendo sujeto gramatical con sujeto ontológico 8 . "La 'razón' en el lenguaje", exclama: "¡oh, qué vieja hembra estafadora! Me temo que no nos libraremos de Dios mientras sigamos creyendo en la gramática" (Nietzsche, 2002, p. 63).

La pretensión ontologizadora del lenguaje es aplicable a las élites letradas bogotanas finiseculares a la hora de codificar las marcas del poder político y religioso en la corrección gramatical, puesto que su sintaxis intenta nominar, ordenar

7 "En realidad", escribe Niebles, "la gramática es una especie de trans-manual que acoge materias diferentes con el pretexto de "enseñar la lengua" y lo que se pretende no es solamente que el nuevo ciudadano hable y lea correctamente, sino también que se comporte, que actúe, que piense correctamente (...) De hecho, su lectura era forzosa por parte de quien deseara ser culto o convertirse en letrado" (2007, p. 12).

8 Para una revisión de la crítica nietzscheana a las ficciones de la gramática, véase Moreno Sanz (2008, pp. 240-281). 
y catalogar la experiencia del ser'. Intelectuales, educadores, políticos y poetas como Rafael Uribe Uribe, Miguel Antonio Caro, Rufino José Cuervo, José Manuel Marroquín, Marco Fidel Suárez y José Abadía Méndez se habían preocupado, en efecto, por consolidar su capital simbólico tomando como bastión el dominio de la lengua castellana.

El proyecto, que tuvo preocupaciones identitarias, como las del continentalismo de Andrés Bello, perpetúa toda una aséptica de lo poético hasta bien entrado el siglo XX. La obra de Miguel Antonio Caro es ejemplar: desarrolla una ambiciosa teoría del origen del lenguaje en la que la palabra aparece como revelación divina. Caro entiende la imaginación del poeta como un "canal intermediario empleado por lo divino para fijar en la humanidad desde los tiempos más remotos $(. .$. imágenes que hablan del poder y la sabiduría de lo trascendente" (Ramírez, 2011, p. 66). Desempeñado como médium, o entregándose al arrobamiento celeste, el poeta no participa ni racionalmente, ni por una vigilada techné, de la cognición divina. Dios "rara vez, si alguna, concede al genio creador la facultad de analizar. El genio produce por instinto, como la fecunda naturaleza física, sin conciencia clara de lo que hace, frutos maravillosos" $\left(\right.$ Caro, 1920, p. 148) ${ }^{10}$.

La propuesta de Caro se detiene en un lenguaje sublimado, siempre al límite de sus fuerzas, en la medida en que pugna por contener una inefable luz. Como en el "Ion o de la poesía" platónico, el poeta es poseído por un saber paradójicamente incomunicable. Rafael Pombo, en este mismo sentido, define poesía y religión como "dos revelaciones de una misma verdad", como "dos faces [sic] de un mismo astro" (citado por Jiménez, 1994, p. 74). Opinión sostenida décadas más tarde por una inteligencia tan estructurada como la de Rafael Maya, en su poema "A una copa antigua", donde celebra en cincelados versos la perduración del arte griego y su redención cristiana ${ }^{11}$. Verdad solo cognoscible -pero nunca limitada por su forma- mediante una palabra-espejo o palabra-vehículo en que la gramática y la ortodoxia religiosa se unirán como privilegiadas vías de acceso a la "esencia" del ser.

\section{El poema como rosa secreta: femineidad y saber poético}

Estas diversas gramaticalizaciones o hipostasis del ser sobre las cuales hemos hablado alcanzan especial fuerza, sin embargo, no en la alabanza a los héroes, a la raza o a las costumbres, como se esperaría de un proyecto político nacionalista, o como lo viera en su momento el romántico José Joaquín Ortiz (1859, p. IV) -el deber ennoblecedor y civil de la poesía-, sino en una de las construcciones más recurrentes de la tradición amorosa occidental: el cuerpo de la amada. Esto no debería entenderse como un particular acento en las narraciones del cuerpo femenino -que haría parte de una crítica contenidista, y por lo tanto, dicotómica del poema-, sino en cómo el código corporal dominante de la femineidad estructura el ideal poético en lo que, a falta de otro nombre, llamaremos el proyecto cognitivo de la lírica tradicional colombiana.

Afirmación que no incurriría en novedad alguna, si advertimos que la lírica tradicional elige casi siempre como objeto

9 Niebles (2007) repara en cómo las gramáticas, más que los códigos civiles, los catequismos y manuales de urbanidad -cuyos límites disciplinares se lo impiden- reproducen mejor las ideologías de la clase dominante, al ejemplificar sus normas lingüísticas con una fraseología que puede acudir, cuando sea necesario, tanto al discurso religioso como al político o moral.

10 Caro encuentra en la mística española el esplendor de un singular des-ocultamiento, en el cual el lenguaje es restaurado como vehículo natural de la voz celeste. Los poetas católicos Luis de Granada y Santa Teresa, en su opinión, habrían accedido a una mostración de la verdad, porque su palabra se moviliza con un impulso sagrado.

11 "Vástago de los tiempos más remotos/yo te sabré guardar, copa exhumada,/ como he guardado los altares rotos/ en donde fueras ya sacrificada/ por el Hombre divino que traía,/ sobre la mansa frente coronada,/ toda la luz con que se anuncia el día" (Maya, 1925, p. 132). 
poético a la "amada". Pero si tenemos en cuenta que el estrecho vínculo entre "teoría" y "escritura lírica”, y la tendencia metapoética de esta última, contribuyen a la "definición de su propia legitimidad" (Cabo, 1999, p. 14), encontraremos una de sus más interesantes especificidades: una forma de pensamiento que reflexiona sobre su estatuto ontológico ${ }^{12}$. Vemos así cómo un modernista tardío como Eduardo Castillo o un piedracielista como Jorge Rojas reflexionan sobre lo poético sustancializando la femineidad bajo un imaginario androcéntrico. Las mujeres de sus poemas están allí para ser contempladas, perdidas: absolutamente puras en su soledad. Amplifican valores como la transparencia y la elevación, y se adscriben, más que a una corporalidad específica, a la aspiración absoluta de lo bello: "Muchachas que prestáis arquitectura/ temblorosa a los aires noche y día,/ y sostenéis con vuestra mano pura/ el firmamento de la poesía" (Carranza, 2007, p. 38).

El poemario del que proceden estos versos de Eduardo Carranza - Azul de ti (1944)no hace otra cosa que mantener una certidumbre genésica: la fuerza poética y, sobre todo, la autenticidad lírica radican en la exaltación amatoria y en la relación consubstancial de la amada con los elementos de la naturaleza. Proyección "inconsciente de la concepción piadosa de la Mujer", en palabras de Eduardo Gómez sobre la poesía de Arturo Camacho Ramírez, idealiza la sensualidad, asimilando la naturaleza a una "imagen excelsa de la Mujer respecto a la cual el poeta (...) adopta la actitud caballeresca de una 'declaración de amor' " (1976, pp. 13-14). En estas líneas de Gómez, escritas un par de décadas después de publicado el poemario de Carranza, se compendia bastante bien lo que caracterizó no solo al poeta villavicense, sino a Jorge Rojas, Carlos Martín y Gerardo Valencia: un neoromanticismo idealista y una retórica cortesana de ascendencia hispánica. Piedra y Cielo mantendrá intacta así, en la década del cuarenta, la búsqueda de una trascendencia centrada en una belleza superior, pero asumiendo por completo -al menos en sus poetas más mediáticos- lo que hasta entonces había sido presentado como isotopía o convención temática: la representación femenina, para convertirla en una poética explícita: "Olía a cielo, a ella, a poesía" ("Elegía pura") (Carranza, 2007, p. 31).
La representación del cuerpo femenino en el discurso poético piedracielista se adscribe a un tópico de la tradición amorosa, pero el código de la representación corresponde a uno de los modos como se construye un soporte cognitivo del discurso poético, independientemente de que el "objeto" cantado sea la mujer. Carranza espiritualiza lo femenino hasta el punto de identificarlo no solamente con el cuerpo inmaterial de la mujer, sino con la forma ardiente de la rosa. "Soneto a la rosa" perfila una depurada elevación de la poesía como rosa "perfecta", de "hermosura vana" y salvada del olvido: "Existe inaccesible a quien la cante,/ de todas su espinas ignorante,/ mientras el ruiseñor muere por ella" (2007, p. 40). Como emblema de lo eterno y lo transitorio, su ambivalencia desea la inmortalidad, pero continuamente está asechada por el tiempo. No puede ser de otra forma en estéticas sublimadas donde la rosa aparece como la melancólica forma que el lenguaje toma para nombrar lo innombrable.

Tributario del paganismo celta -que identifica lo femenino con la naturaleza-, del gnosticismo y el catarismo que condena la corporalidad y la sexualidad procreadora- o

12 Ello no desvirtúa, por supuesto, la arbitrariedad del vínculo entre "poesía” y "mujer", o entre lo "poético" y lo "femenino". Berrío, Genette, Guerrero, MacLean y Pozuelo "sitúan la tensión entre la mímesis y la expresión, o incluso la efusión sentimental, la revelación o el conocimiento, en el centro del debate teórico en torno a la lírica (...) Sin olvidar la dimensión lingüística (...) la conciencia formal” (Cabo, 1999, p. 10). 
del cristianismo escolástico cuya visión teológica vincula al cuerpo humano con el Verbo como imitatio Christi-, el primer Carranza centra sus apetencias cognitivas en una exaltación gozosa, motivada por una amada imposible. Para Rosa Rosi, en Breve historia feminista de la literatura española, el discurso sobre el amor y la mujer en la tradición cortés siempre ha hablado de "otra" cosa, como de "temáticas religiosas en sentido heretical respecto a la ortodoxia eclesiástica" (1993, p. 24). La donna dantesca, si seguimos este razonamiento, excede como pocas amadas los límites de la racionalidad humana para, inflamada de deseo ascético -negación corpórea y sexual-, remontar al poeta a las más inaccesibles esferas, convirtiéndose ella misma en poesia ${ }^{13}$. Lenguaje divino y "bella espresión [sic] de lo bueno i [sic] de lo verdadero" (Ortiz, 1859, p. IV), la verdadera poesía habla entonces de lo que nunca cambia a través de la sublimación de lo que siempre está mudando. "La forma de tu rostro", celebra Jorge Rojas, "es la misma que engendra/órbitas y estaciones sobre sus claros ejes/y da normas al sol, la luna y las estrellas,/ y gobierna el transcurso de la rosa y la nieve" ("Nocturno de Adán”) (1998, p. 42$)^{14}$.

Esta contemplación obedece a una dialéctica de la imagen y el reflejo, en la cual el "objeto" celebrado -la mujerse convierte en medio de acceso al orden sobrenatural, pero siempre como renuncia a su inmediatez, a su propia opacidad erótica. El poeta ofrenda al infinito la materialidad de la amada: la convierte en un camino de símiles que no puede ser tocado, a riesgo de corromperse. El culto espiritual a lo femenino coincide así con el desarrollo de un discurso poético que hace gala de impunes sincretismos desde su misma formación, "un intento de sintetizar la retórica de eros, el amor humano, con la de ágape, el amor a Dios", hasta el punto de que, como lo asegura Wardropper, "el lenguaje del amor profano est[é] completamente confundido con el de la religión" (citado por Gerli, 1980, p. 316 $)^{15}$. Una tensión erótica similar, pero procurada por la enfermedad y el hastío modernista ${ }^{16}$, se encuentra en la novela De sobremesa (1925), de Silva:

¡Oh! ¡Ven, surge, aparécete, Helena! Lo que queda de bueno en mi alma te reclama para vivir. Estoy harto de la lujuria y quiero el amor; estoy cansado de la carne y quiero el espíritu (...) Si sobre mi cuerpo crispado de voluptuosidad se pasearon manos buscadoras y lascivas (...) fue porque no te había visto todavía. Ten piedad de mí (1984, p. 264).

Eduardo Castillo, poeta muy valorado por el piedracielismo, retomaba en las primeras décadas del siglo XX la tradición que diviniza a la "amada", cultivando una línea estética que, además de asumir como motivo poético a la mujer, explora sus posibilidades semióticas. Es importante, en este aspecto, volver al malestar pronunciado por el escritor cartagenero V. M. García Herreros, en 1925, ante los versos de "la amada insensible", la "tristeza crepuscular", "el amor incorrespondido" y la "amada ingrata" (citado por Castillo , 2006, pp. 219-220), para medir el agotamiento de un tópico y de una forma de

13 Beatriz cifra en este sentido, para Varela-Portas, la capacidad de la poesía de imaginar espiritualmente, de comprender lo imaginado y remontarse a las verdades veladas por las imágenes como una intelligenza nova; pues, de creer a Ricardo de San Víctor, la razón requiere de la imaginación para funcionar (2008, p. 17).

14 Versos que recuerdan no sólo los tercetos finales de la Commedia del Dante, sino también a Guido Guinizelli: "Quiero ver a mi dama alabada/ y asemejarla a la rosa y al lirio:/como el lucero aparece resplandeciente,/ y todo lo que en el cielo haya de bello, a ella lo asemejo// A la verde rivera y al aire la comparo,/ a todos los colores y las flores" (traducción de Roberto de Espada Vicente).

15 Plegarias, letanías, rezos, misas y rituales son adaptados a una retórica amorosa, sin menoscabo de su solemnidad (Gerli, 1980, p. 316).

16 Un interesante ensayo sobre la enfermedad y el discurso médico en los cuerpos masculinos de la novela de Silva se encuentra en Giorgi (1999). 
concebir la poesía. Imagina Eduardo Castillo la "naturaleza" esquiva y promisoria del ideal femenino: "Y aunque no pude ni encontrar su huella/ [...] algo me mueve/ a seguir caminando en busca de ella" ("Difusión") (1997, p. 258). Beatriz, Laura, Desdémona, Julieta o Leonora, son algunos de los nombres que constelan en sus versos bajo una prestigiosa amatoria: la de los amores negados. Celestes madonas, sombras suspirantes y fantasmas oníricos, frágiles como "una lámpara que apenas ilumina" (Rojas Herazo, 2003, p. 261). En 1950, Rojas Herazo escribiría sobre Castillo: la "arquitectura de sus mujeres ideales no tienen (...) contornos definidos. Están situad[a]s en esa mágica frontera de la vigilia y el sueño" (p. 122).

La "feminización" del ideal en Castillo viene mediada por una tradición romántica y modernista, con sus múltiples matices celestes o infernales. Ya sea como encarnación o espiritualización de una idea, apunta a una finalidad cognitiva: sus mujeres siempre son menos mujeres individuales de lo que podrían ser. Lo que aquí define de "una manera singular la situación de la mujer", como sostiene De Beauvoir,

es que, siendo como todo ser humano una libertad autónoma, se descubre y se elige en un mundo donde los hombres les imponen que se asuma como lo Otro. Se pretende fijarla en objeto y consagrarla a la inmanencia, ya que su trascendencia es perpetuamente trascendida por otra conciencia esencial y soberana (2010, p. 31).

Desde este juego, lo femenino posibilita la salvación, pero también la caída; su corporalidad se dilata, hasta confundirse con el universo, pero se reduce hasta ontologizar la culpa. En el ámbito lírico, la elisión de una "conciencia esencial y soberana" conduce a una dicotomía lingüística defendida por varias escuelas poéticas tradicionales, para las cuales la sola desviación de una función comunicativa y didáctica rebaja el poema a "decadencia". Lo femenino, como materia irracional, y lo masculino, como intelectualidad, tienen su correlato en la concepción heterónoma del poema como compuesto dual de forma y contenido.

Como es de esperarse, la preeminencia del contenido encierra en las "teorías" artísticas del XIX y el XX dilemas no solo estéticos, sino políticos y religiosos, que encuentran sus antecedentes históricos en un cristianismo platonizado -virtualmente herético- y en una cosmovisión filosóficoteológica que separa el mundo entre cuerpo y alma, materia y espíritu. En Fábulas y verdades, Rafael Pombo afirma: "Nuestro cuerpo es la caja, el hospedario/ de un reloj inmortal; y aunque el primero/ se hunda en la mar, o el fuego lo consuma, / el alma, hoy a los ojos escondida,/ seguirá andando, y con su andar, la vida" ("El alma") (1984, p. 21). Traspuesto al plano estético es una concepción análoga a la del poema como entidad bipartita o efluvio divino, si acudimos a Miguel Antonio Caro. De modo que para un modernista de corte parnasiano como Guillermo Valencia la autonomía poética no podía ser practicable: la "poesía no es más que 'la forma graciosa en que culminan procesos anteriores de mayor trascendencia", (Jiménez, 1994, p. 74).

En su programa de dilución del ideal metafísico, Luis Carlos López concede un lugar notable a la ironización de estos valores dualistas cortesanos y románticos. He ahí poemas como "Para ti", "Visión inesperada", "A Lulú", "Pasas por la calle", "El despertar de Pan", "Mi azotacalles" o "Campesina, no dejes", donde la materialidad del cuerpo de la amada, la sexualidad de sus maneras, la acalorada entonación de su priápico admirador, enturbian las convenciones del amor occidental, con sus tópicos del "mirar" y el "ver". En "A Rosalbina", incluido en Por el atajo (1920), el cartagenero ironiza la retórica petrarquesca, sus rituales emotivos y composicionales, como el prestigio del morbo sacro o la ciudadanía amatoria del soneto, y las malignas hadas del modernismo. Imagina López una mujer cuyo nombre connota una sutil contradic- 
ción: la albura epidérmica de la rosa -Rosalbina-, vinculada al quebrantamiento moral y físico del amante y a la vulgarización del símbolo sagrado pensamos en la rosa intacta de Jean de Meung en el Roman de la rose o en la fugacidad floral de Malherbe-.

El hablante lírico, conmocionado por el mirar felino de la amada, confiesa: "Bien sabéis, adorable Rosalbina,/ que ante vuestro mirar de ojos de gato,/ me sentí como calle sin esquina,/ ¡bizco y sordo y maltrecho y turulato!//... ¿Por qué sois para mí luciferina.../ ¡Si ha mucho tiempo que estoy disparato" (López, 1984, p. 116). El desequilibrio orgánico, sin embargo, no es motivado por una insensata pasión. El poeta ha abusado tiempo atrás del piramidón y la morfina, del bromuro y el bicarbonato: su enfermedad deriva de un mal corporal, no de un estremecimiento amoroso sublimado. En Gotas amargas, Silva adelantó años antes una desacralización similar de la pureza femenina: "Tu tez rosada y pura; tus formas gráciles/ (...)/ El carmín de tu boca de labios tersos;/ (...)/ Tu mano blanca y fina, toda hoyuelada,/ (...)/ Tu voz, tus ademanes, tu... no te asombre:/ Todo eso está, ya a gritos, pidiendo un hombre" ("Madrigal") (2003, p. 71).

El hablante de "A Rosalbina" justifica su estremecimiento como resultado de una enfermedad óptica -parodiando los espléndidos encuentros visuales de Dante, Petrarca y Boccaccio (cf. Santos, 2006, pp. 13-14) y las mohínas fisiologías decadentistas-: "vuestro marido viéndome patojo// y con ganas de hacer un disparate,/ me preguntó solícito: -¿Qué hay, vate? / Y yo le dije unísono: -Un mal de ojo" (López, 1984, p. 116). ¿Puede la lírica colombiana seguir hablándonos de lo eterno sin presentir su agonía? ¿Puede retornar la instructiva celeste de Núñez y Caro? No es excesivo afirmar en este punto que la pugna por el código corporal femenino marca uno de los momentos más importantes en la de-construcción del ideal canónico de la poesía colombiana. Raúl Gómez Jattin, por citar uno de los ejemplos más ilustrativos de la década de los ochenta, lo somete a una radical y tierna obscenidad, que obliga a replantearse formalismos y esencialismos ortodoxos como "lenguaje poético" y "belleza". En Del amor (1987) -título que dialoga con las eróticas de Platón, Ovidio y Capellanus-, escribe: "Maritza Qué nombre tan horrible Como su/ cara Pero tenía un culo que sacaba la cara por ella/ Y unas tetas como papayas blanditas/ que no había necesidad de tocar" ("Venía del mercado excitada y dispuesta") (2004, p. 110).

¿Cuáles son las consecuencias de este nombramiento de la corporeidad femenina? Si en
Gómez Jattin, como señalan Agámez y Serrano, lo masculino es construido por medio de metáforas platonizadas, "la imagen femenina, a menos que (...) no esté revestida por la evocación del amor en la infancia o la amistad" (2012, p. 91) cuenta con un lenguaje que se libera de sutilezas. La corporeidad se incendia por el deseo, por el tacto y el anhelo del otro. El panerotismo, o comulgación prenatal con los órdenes racionalizados del existir -lo animal, lo vegetal, lo humano-, afirma una vitalidad whitmaniana de la existencia: un cuerpo que no puede ser corregido o domesticado por los presupuestos burgueses. "Todo ese sexo limpio y puro como el amor/ entre el mundo y sí mismo Ese culear con todo lo hermosamente culeable Este metérselo/ hasta a una mata de plátano Lo hace a uno/ Gran culeador del universo todo culeado/ Recordando a Walt Whitman" (“... Donde duerme el doble sexo") (Gómez Jattin, 2004, p. 78).

Tras el paulatino derrumbe del proyecto de una nación unida por una sola lengua y una sola religión, la poesía se desprende de los deberes miméticos. Las críticas de la Generación de Mito, en la décadas de los cincuenta, a las evasiones piedracielistas, y la irrupción nadaísta y de los poetas de la Generación Desencantada, en los sesenta y setenta, respectivamente, cuestionan la legitimidad con- 
servadora del canon poético colombiano. La feminización lírica es subvertida con mayor o menor fortuna, desplazada por una preocupación lingüística que, con una poeta como María Mercedes Carranza confirma el camino al más crudo de los escepticismos contra la tradición patriarcal y la gramática nacionalista: "Por traidoras decidí hoy,/ martes 24 de junio,/ asesinar algunas palabras./ Amistad queda condenada/ a la hoguera, por hereje;/ la horca conviene/ a Amor por ilegible;/ [...]
Esperanza ha muerto ya;/ Fe padecerá la cámara de gas;/ el suplicio de Tántalo, por inhumana,/ se lo dejo a la palabra Dios" ("Sobran palabras") (Carranza, 1995, p. 71). Dialoga María Mercedes Carranza con el deber de un tardío vanguardismo nadaísta formulado por Gonzalo Arango: "No dejar una fe intacta, ni un ídolo en su sitio. Todo lo que está consagrado como adorable por el orden imperante será examinado y revisado" (1974, p. 19). ¿Dónde queda la tras- cendencia poética en este horizonte? ¿Podríamos confiarnos a ella en un orden representacional desprovisto de garantes? Preguntas como estas evidencian una profunda transformación en la legitimación metapoética de la lírica colombiana del siglo XX: la vacuidad de un ideal estético-teológico que para algunos críticos consolida una lírica "moderna", plenamente secular, o podría trascender incluso el concepto eurocentrado mismo de lírica "moderna".

\section{Referencias}

Arango, G. (1974). Obra negra. Buenos Aires: Ediciones Carlos Lohlé.

Agámez, D. y Serrano, C. (enero-diciembre, 2012). Amor y erotismo: la palabra desnuda de Raúl Gómez Jattin. Visitas al Patio, 6, 73-95.

Berman, M. (2008). Todo lo sólido se desvanece en el aire. México: Siglo XXI Editores.

Cabo, F. (1999). La lírica: un lugar teórico. En C. Aseguinozola (Comp.), Teorías sobre la lírica (pp. 9-22). Madrid: Arco/Libros.

Caro, M. A. (1920). Obras completas. Estudios literarios (vol. II). Bogotá: Imprenta Nacional.

Caro, M. A. (1962). Obras. Bogotá: Instituto Caro y Cuervo.

Carranza, E. (2007). Los pasos contados: Antología de poesía. Bogotá: Norma.

Carranza, M. M. (1995). De amory desamor y otros poemas. Bogotá: Norma.

Castillo, E. (1997). Difusión. En R. Echavarría (Comp.), Antología de la poesía colombiana (p. 258). Bogotá: Ministerio de Cultura, Panamericana, El Áncora Editores.

Cobo, J. G. (1978). Prólogo. En B. Sanín, El oficio de lector (pp. ix-xlvii). Venezuela: Biblioteca Ayacucho.

Cortázar, R. (2003). La novela en Colombia. Medellín: Fondo Editorial Universidad Eafit. 
Deas, M. (2006). Delpoder y la gramática y otros ensayos sobre historia, política y literatura colombiana. Bogotá: Taurus.

De Beauvoir, S. (2010). El segundo sexo. Buenos Aires: De Bolsillo.

De la Vega, F. (1981). Evolución de la lírica en Colombia. Bogotá: Instituto Caro y Cuervo.

Friedrich, H. (1958). Estructura de la lírica moderna: de Baudelaire hasta nuestros días. (J. Petit, Trad.). Barcelona: Seix-Barral.

Gerli, M. (1980). Eros y ágape: el sincretismo del amor cortés en la literatura de la baja Edad Media castellana. En E. Rugg y A. Gordon (Coord.), Actas del VI Congreso Internacional de Hispanistas (pp. 316-319). Toronto: Universidad de Toronto.

Guillén, J. (1997). Poética. En V, De Lama (Ed.), Poesía de la Generación del 27: Antología crítica comentada (pp. 95-98). Madrid: Edaf.

Gómez, E. (1976). Prólogo. En A. Camacho, Carrera de la vida (pp. 13-44). Bogotá: Instituto Colombiano de Cultura.

Gómez Jattin, R. (2004). Amanecer en el Valle del Sinú. Antología poética. México: Fondo de Cultura Económica.

Jiménez, D. (1992). Historia de la crítica literaria en Colombia. Bogotá: Universidad Nacional de Colombia, Instituto Colombiano de Cultura.

Jiménez, D. (1994). Fin de siglo, decadencia y modernidad. Ensayos sobre el modernismo en Colombia. Bogotá: Instituto Colombiano de Cultura.

López, L. C. (1984). Obra poética. Bogotá: Círculo de Lectores.

López, L. C. (2007). Obra poética. Cartagena: Editorial Universitaria.

Machado, A. (2001). Poesías completas. Barcelona: Espasa-Calpe.

Madiedo, M. M. (1859). Poesías, precedidas de un tratado de métrica. Bogotá: Imprenta de la Nación.

Maya, R. (1925). La vida en la sombra. Bogotá: Cromos.

Moreno, J. (2008). El logos oscuro: tragedia, mística y filosofía en María Zambrano (vol. I). Madrid: Verbum.

Niebles, E. (2007). Andrés Bello: la construcción de un orden civil fundamentado en la gramática. Poligramas, 27, 81-97.

Nietzsche, F. (2002). El ocaso de los ídolos. Madrid: Edaf.

Núñez, R. (1986). Poesías. Bogotá: Círculo de Lectores.

Núñez, R. (1970). El sentido de la política y la esencia de la política”. En J. Jaramillo (comp.), Antología del pensamiento político colombiano. Bogotá: Banco de la República.

Ortiz, J. J. (1859). Introducción. En M. Madiedo (1859), Poesías, precedidas de un tratado de métrica (vol. III-VII). Bogotá: Imprenta de la Nación. 
Pombo, R. (1984). Fábulas y verdades. Bogotá: Círculo de Lectores.

Ramírez, J. F. (julio-diciembre, 2011). Miguel Antonio Caro: concepciones estéticas y literarias. Estudios de literatura colombiana, 29, 63-79.

Rojas, J. (1998). Nocturno de Adán. En C. Hernández (comp.), Piedra y cielo (pp. 42-49). Bogotá: Panamericana.

Rojas H. (2004). Obra poética, 1938-1995. Bogotá: Instituto Caro y Cuervo.

Rojas H. (2003). Obra periodística, 1940-1970 (vol. I). En J. García (comp.), Vigilia de las lámparas. Medellín: Universidad de Antioquia, Fondo Editorial EAFIT.

Rosi, R. (1993). Prólogo. En M. Díaz e I. Zabala (coords.), Breve bistoria feminista de la literatura española (en lengua castellana) (vol. I). Barcelona: Anthropos.

Sanín, B. (1977). Escritos. Bogotá: Instituto Colombiano de Cultural.

Sanín, B. (julio-diciembre, 2006). Cosme o el ocaso de los hombres (aproximación a la novela de José Félix Fuenmayor). Cuadernos de Literatura del Caribe e Hispanoamérica, 4, 9-20.

Schulz, W. (1961). El Dios de la metafísica moderna. México: Fondo de Cultura Económica.

Silva, J. A. (1984). Poesía y prosa. Bogotá: Círculo de Lectores.

Varela-Portas, J. (2008). "Viaje con Beatriz”, Tenzone, 9, 179-210.

Vargas Vila, J. M. (1999). Los parias. Bogotá: Panamericana.

Von der Walde, E. (enero-junio, 1997). Limpia, fija y da esplendor: el letrado y la letra en Colombia a finales del siglo XIX. Revista Iberoamericana (vol. LXIII), 71-83.

Von der Walde, E. (2002). Lengua y poder: el proyecto de nación en Colombia a finales del siglo XIX, Estudios de lingüística española, 16. Recuperado de www.http://elies.rediris.es/elies16/Erna.html 